\title{
Medical Malpractice Appeals in a Civil Law System: Do Administrative and Civil Courts Award Noneconomic Damages Differently?
}

\section{Sofia Amaral-Garcia}

How do courts award noneconomic damages? Does it matter if the state is the defendant? This article addresses these questions in the context of medical malpractice appeals to the Spanish Supreme Court. Moreover, this study provides the first empirical analysis of the quantification of noneconomic damages in medical malpractice cases in administrative courts, where the state is the defendant, and in civil courts. This separation of jurisdictions is a common feature in civil law tradition countries. Yet, critics of this separation in general, and specialized courts in particular, argue that parties might be subject to different treatments and that similar cases might reach different outcomes, namely in terms of the quantification of damages. A consistent result of this paper is that no significant differences between noneconomic damages in civil and administrative appeals were found. The separation of jurisdictions does not necessarily imply that courts reach different outcomes, even when the state is the defendant. Citizens should not refrain from bringing their claims forward against the state, a more powerful party. In the current era of increasing juridification and judicialization of modern life (Ginsburg 2009; Hirschl 2006; Hirschl 2011), it is crucial for society that citizens and other parties litigating with the state are not disadvantageously treated.

$\mathrm{H}$

ow do courts award noneconomic damages? Does the answer to this question change if the state is the defendant? Understanding the outcomes of court cases involving the state is crucial for any society because a relevant proportion of litigation involves the state and these decisions affect a large number of citizens and private parties. In this article, I provide the first empirical analysis of the quantification of noneconomic damages in medical malpractice appeals in Spanish administrative courts,

I am grateful to Ted Eisenberg, Michael Faure, Nuno Garoupa, Fernando GomézPomar, Gerard Hertig, David Hyman, Jonathan Klick, Sonia Ramos, Louis Visscher, Rainer Winkelmann, and the participants at the European Conference on Health Economics (Zurich), AEDE (Valencia), ETH Zurich, and the University of Zurich for helpful feedback. I am particularly grateful to Mattia Nardotto, the reviewers, and editors at the Law \& Society Review for their insightful comments on this paper (previous tittle: "Noneconomic Damages in Medical Malpractice Appeals: Does the jurisdiction make a difference?"). Financial support is acknowledged to FCT, Portuguese Ministry of Higher Education and Science, grant SFRH/BD/37917/2007.

Please direct all Please direct all correspondence to Sofia Amaral-Garcia, Hasselt University, Agoralaan, Building D, 3590 Diepenbeek, Belgium; sofia.amaralgarcia@uhasselt.be. 
where the state is the defendant, and in Spanish civil courts. Spain is a civil law tradition country, as are approximately two-thirds of the legal systems worldwide (Mahoney 2001).

The specific empirical focus of this article is on Supreme Court (hereinafter SC) appeals. More precisely, this article starts by considering medical malpractice appeals ${ }^{1}$ to the Spanish Supreme Court (hereinafter SSC) from 2006 through 2010, examining whether or not there are case characteristics that predict a positive payout. Subsequently, the article uses the legal separation between administrative and civil jurisdictions (a feature common to other civil law tradition countries) to test whether administrative courts award noneconomic damages differently than civil courts ${ }^{2}$ (economic damages which, in this setting, comprise essentially loss of income and medical expenses are excluded). Medical malpractice cases in civil law tradition countries generally can be tried in different courts. In some legal systems such as in that of Spain, medical malpractice claims can be brought to either administrative courts or civil courts, depending on the identity of the defendant (private or public healthcare provider). Therefore, whenever a medical accident takes place in a public hospital, patients should file their claims in administrative courts and whenever a medical accident takes place in a private hospital, patients should file their claims in civil courts. This means that the state is inevitably the defendant in administrative cases. The division of jurisdictions is a typical feature of civil law tradition countries where, as Merryman and Perez-Mordomo (2007): 86) describe, it is "usual to find two or more separate sets of courts, each with its own jurisdiction, its own hierarchy of tribunals, its own judiciary, and its own procedure, all existing within the same nation." Civil law tradition countries make a strong distinction between private law and public law. Administrative courts specialize in administrative law ${ }^{3}$ (a branch of public law focusing on public administration) and, therefore, mainly adjudicate cases involving the state. Administrative courts resolve disputes that are specific to the role of the state and protect citizens from state overreach. Moreover, administrative courts can be asked to perform judicial review of administrative decisions (e.g., to determine if a public

1 For more on the Spanish legal system in medical malpractice cases, see Ferrara et al. (2013), Koch (2011), Arroyo and Yágüez (2013), Martin-Casals et al. (2003), Amaral-Garcia (2015b), Amaral-Garcia and Garoupa (2015) and Amaral-Garcia (2017).

${ }^{2}$ Although the issue of specialized administrative lawmaking has received some attention in the U.S., the institutional arrangements are remarkably different.

${ }^{3}$ Despite this common feature in civil law tradition countries, there is no unique model for administrative courts or for the adjudication of litigation involving the state (Amaral-Garcia 2015a). 
body acted beyond the scope of its powers or if a public body failed to act or perform a duty statutorily imposed on it). ${ }^{4}$

This separation of jurisdictions ${ }^{5}$ has led some scholars to consider it as an example of inefficiency in legal governance in civil law tradition countries. ${ }^{6}$ One argument is that the civil law tradition "assumes a larger role for the state, defers more to bureaucratic decisions, and elevates collective over individual rights. It casts the judiciary into an explicitly subordinate role" (Mahoney 2001: 511).

Courts play a crucial role in adjudicating cases, and they have an impact on citizens and society; they also matter for economic growth and development (Mahoney 2001). Moreover, courts are also relevant for policy: courts are one institutional actor in the making of policy - they are neither insignificant nor capable by themselves of transforming politics without other institutions (Sterett 1994). It is therefore important for courts not to have a bias in favor of any particular party in the litigation process, and this holds for every type of case. Cases involving the state are naturally also included in this consideration, particularly nowadays that the state is a constant presence in many spheres of daily life, its powers vast and its functions quite complex (Amaral-Garcia 2015a). The state has particular functions that private citizens do not have, such as the declaration of war, collection of taxes, issuance of passports, and the monopoly of legitimate coercion (Cane 2011).

When considering the outcomes of court cases involving the state or the government, there is some evidence that the government may fare better than private parties in terms of case duration (Bielen et al. 2015) or in terms of obtaining reviews and reversals of lower court judgments (Eisenberg et al. 2011). This could raise concerns, especially in a period of increasing juridification and judicialization of "modern life" (Hirschl 2006), which entails the spread of legal procedures into social and political spheres and an expansion of the role of courts and judges in

${ }^{4}$ In the U.S., much of administrative review is vested in public authorities and independent agencies, often described as administrative tribunals (Cane 2010; Amaral-Garcia 2015a). For the English case, see Sterett (1997).

${ }^{5}$ Additionally, civil law tradition countries can also have the Constitutional Courts adjudicating cases involving the state. Generally speaking, administrative courts adjudicate primarily cases related to the executive function of the state, and constitutional courts adjudicate cases related to the legislative, judicial, and executive functions (Amaral-Garcia 2015a). This is the case in Spain.

${ }^{6}$ There is a long debate on legal origins that suggests that common law countries are more efficient than civil law countries (i.e., that the common law system is more conducive to economic growth than the civil law system). See, for example, Mahoney (2001) and LaPorta et al. (2008). For a critique of this hypothesis, see Garoupa and GomezLiguerre (2011). Cross and Donelson (2010) focus on the quality of the court system, finding a negative correlation between common law and the quality of courts in Europe. 
determining public policy outcomes (Ginsburg 2009; Hirschl 2006; Hirschl 2011). ${ }^{7}$ It is relevant for society that citizens are not treated disadvantageously when dealing with the state; otherwise they might refrain from bringing their claims forward against a more powerful party.

Comparing cases of private litigants with cases in which the state is a litigant poses the challenge of finding cases that are similar, differing only with respect to the type of litigants. In Spain, medical malpractice cases are good case studies for this comparison: in practice, even though cases involving public or private hospitals end up in administrative or civil courts, respectively, they follow the same rules concerning liability, causation, burden of proof, quantification of damages, grounds for reversal, and court fees, to name a few areas of similarity (AmaralGarcia and Garoupa 2015). ${ }^{8}$ These cases, therefore, provide a good setting for comparing administrative and civil court decisions, in particular with respect to the quantification of noneconomic damages.

Another relevant feature is that administrative courts and civil courts are very similar in terms of practical functioning and legal responsibilities. The same holds with respect to judges practicing in these courts, in terms of training and judicial career, which makes for a very different framework in comparison with the U.S. In fact, a jurist trained in the U.S. might face some difficulties when trying to understand the functioning of administrative courts and the profession of administrative judges in continental European civil law tradition countries (AmaralGarcia 2015a). In the U.S., for instance, administrative judges have very different careers from civil judges and do not enjoy life tenure (see, for example, Ryo (2016) on immigration judges). In Spain, as in the majority of civil law countries in continental Europe, administrative judges follow the career of a generalist judge, specializing in administrative law when serving in administrative courts. ${ }^{9}$

${ }^{7}$ Hirschl (2011) defines judicialization "from below" as the legal mobilization by groups and movements that aim to advance social change through constitutional rights litigation. In Spain, constitutional review (both concrete and abstract review) is conducted by the Constitutional Court (Garoupa et al. 2013).

${ }^{8}$ In fact, there are no particularities in medical malpractice cases involving the state as defendant that would potentially justify the need to have specialized courts deciding these cases.

${ }^{9}$ France is an exception: most of the members of the Conseil d'Etat are civil servants, the "crème de la crème of the National School of Administration" (Latour 2009) the elite school for training French government executives. See Latour (2009) for a detailed sociolegal analysis of the Conseil d'Etat. 
The focus of this article is on SC decisions which are relevant for many reasons, namely because they make new law, clarify the law, produce precedents, harmonize conflicting lower court decisions, and allow for error correction (Shavell 2010). In civil law countries, parties' right to appeal to the SC makes the number of appeals high and the majority of appeals might actually fail. ${ }^{10}$ All of these reasons make the study of SC decisions particularly interesting in civil law countries.

This article proceeds as follows. Section "Previous Research and Theoretical Framework" reviews relevant previous research and describes the theoretical framework of the current analysis. Section "Medical Malpractice in Spain" describes the medical malpractice liability system in Spain and the quantification of damages. Section "Dataset and Descriptive Statistics" describes the dataset. The methodology and main findings are presented in Section "Methodology and Results," which includes robustness checks using matching and simulation exercises. Section "Discussion" discusses the main results. Section "Conclusions" concludes the article.

\section{Previous Research and Theoretical Framework}

I integrate insights from two major lines of research: the literature on medical malpractice damages, in general, and noneconomic damages, in particular, by courts in civil law tradition countries; and the literature on the division of jurisdictions and on specialized courts. Moreover, this article advances prior literature by combining analysis of the quantification of noneconomic damages in medical malpractice cases with that of the distinction between civil and administrative jurisdictions. In spite of the debate on possible differences between administrative and civil courts, the lack of empirical evidence has generally made it hard to draw conclusions.

I now provide a brief overview of the steps in medical malpractice cases, in particular of how damages are set. What happens when a medical error occurs and a patient brings a claim to court? Courts first assess whether the doctor was negligent and, if so, if the substandard acts resulted in the injury. When courts decide that substandard treatment caused the injury, a quantification of damages follows. The quantification of damages is crucial

${ }^{10}$ This claim is confirmed by medical malpractice cases appealed to the SSC: the majority of cases see the previous decision affirmed and with the same outcome in every court and in every step of the litigation. This also adds to the evidence that there is no particular selection effect in terms of cases appealed to the SSC in comparison to lower courts. Additional arguments have to do with the very low cost of appealing to the SSC, appeals being on points of law and not facts, and the SSC has no control over its docket (Amaral-Garcia and Garoupa 2015). 
for medical malpractice cases: the compensatory goal of tort law requires that the injured patient be made "whole" and should also deter negligent medical care (Arlen 2000; Visscher 2009). The general rule is that patients should be fully compensated for the harm suffered, with courts tending to award economic and noneconomic damages. ${ }^{11}$

While economic damages are considered easier to compute, noneconomic damages are seen as more controversial and difficult to quantify (Avraham 2006; Avraham 2017). This component of damages should attribute a monetary value to the pain and suffering sustained by victims - mental anguish, emotional distress, loss of consortium, and emotional losses (Croley and Hanson 1995). Pain-and-suffering damages are frequently under attack, however, given the difficulty of quantifying them. Some contend that they end up being highly variable, unpredictable, arbitrary, and inconsistent (Bovbjerg et al. 1989; King Jr. 2004), and thus should be abolished. Others acknowledge the difficulties in computing them, but argue that the focus should be on developing ways to make these damages more consistent (Avraham 2017). Despite the controversies regarding noneconomic damages, courts in different legal systems, such as the U.S., western Europe, Canada, and Australia, do award them (Comandè 2009; Sugarman 2005; Karapanou and Visscher 2010 and Leiter et al. 2012).

Noneconomic damages are a valuable part of the tort system: when set in a nonarbitrary and consistent way, they help to maintain the deterrent function of tort law by discouraging potential tortfeasors from exercising insufficient levels of care (Bovbjerg et al. 1989; Geistfeld 1995; Shavell 1987). Two characteristics should be observed when examining noneconomic damages: vertical inequality and horizontal equity. In other words, patients suffering higher levels of injury should receive higher noneconomic damages and patients suffering similar injuries should receive an equivalent indemnity award. ${ }^{12}$

So far, the empirical evidence on the attribution of medical malpractice damages in civil law countries is limited. ${ }^{13}$ Chang et al. (2017) consider the case of car accidents and medical malpractice in Taiwan, finding that pain and suffering damages strongly correlate with medical expenses, injury level, and the

11 Some jurisdictions, such as the U.S., also award punitive damages. The attribution of punitive damages tends to be rare and these are only awarded under certain circumstances, generally requiring more than negligence (e.g., gross negligence, attempt to cause intentional harm). See, for example, Cooter 1988.

12 This article does not assess how damages should be calculated or what is the fair or optimal compensation amount that victims should receive.

${ }^{13}$ Grembi and Garoupa (2013) assess SC decisions of medical malpractice in Italy, but the amount of compensation awarded is not generally available. 
amount requested by the plaintiff. Flatscher-Thöni et al. (2013) analyze Austrian courts' decisions in order to investigate whether the use of per diem or lump-sum schemes influence the amount of pain and suffering damages. They find that per-diem courts award significantly lower noneconomic damages than lump-sum courts. Flatscher-Thöni et al. (2015), in considering court decisions from Germany, find that pain and suffering awards depend on injury-specific characteristics, the court in which the case was decided, and whether or not the plaintiff had a lawyer.

I now turn to the consideration of the division of jurisdictions and specialized courts, in particular with respect to the role of the state. Should the adjudicative function of administrative cases be vested in separate bodies? In the U.S., there is a strong focus on administrative agencies, even though some cases (e.g., immigration detention) can be considered civil or administrative (Ryo 2017). Immigration has become very contentious across Europe and the U.S., and scholars have debated the role of administrative courts and administrative adjudication in these cases (e.g., Hamlin (2016), Ryo (2017), Sterett (1994), along with references therein). ${ }^{14}$

To continue the discussion above on whether the adjudicative function of administrative cases should be vested in separate bodies, we should also ask, if so, are courts the most appropriate institutions? Should there be specialized administrative courts to resolve litigation with the state? Specialized courts have been debated for decades, but the issue remains controversial, with several arguments both in favor and against specialized courts (Baum 2011; Dreyfuss 1990; Nutting 1955; Revesz 1990). As well, several of the arguments on specialized courts can be easily extended to administrative courts. Judicial specialization can bring "neutral virtues" such as the quality of decisions, uniformity of the law, and efficiency (Baum 2011). If the adjudicator becomes an expert in a certain type of decisions, this can lead to more correct decisions in complex areas of the law (something particularly relevant in fields of law that involve complex technical skills). Moreover, decisions can then become more uniform and coherent. Having a separate jurisdiction to adjudicate cases involving the state can have some advantages. In that situation, judges could acquire appropriate training so that they become experts in administrative law, and

${ }^{14}$ There is a contentious debate about the role of courts in adjudicating asylum and the degree of deference that should be afforded to administrative agencies by courts. Hamlin (2016) finds remarkable institutional differences between the U.S., Canada, and Australia when dealing with the same types of cases, as each country has a distinct conception of administrative justice and how that shapes refugee status determination regimes. Sterett (1994) offers an in-depth analysis of immigration cases in Britain, which make up a substantial part of the business of the courts. 
procedures in court can be tailored to deal with the particular features of the state as defendant (Dari-Mattiacci et al. 2010). Bell (2007) argues that a major advantage of separate administrative courts is the possibility to develop a set of principles that accepts the specific nature of the state as defendant the balancing of the interests of citizens and legal rights, and the ability of the administration to pursue the public interest (e.g., Sterett 1997). There are also possible "nonneutral effects" of specialized courts on the substance, namely a change in the ideological content of judicial policy or the support for competing interests in a given field (Baum 2011).

There are, however, potential disadvantages as well. Specialized courts might apply the law in a narrower way, and have fewer skills in applying concepts from other areas of law when necessary. When considering the case of administrative courts, one argument is that administrative judges might be deferential to the state, as the marginal cost for a judge in deciding against the state is higher in administrative courts than in ordinary judicial courts (Mahoney 2001). Accountability becomes more difficult with specialization, because the knowledge of administrative law is specific for administrative judges, who might become more dependent on the state precisely for this reason (Dari-Mattiacci et al. 2010). As a result, administrative judges might have difficulties in realizing that the state has overreached, whether because judges exhibit systemic biases or because judges want to keep their status as state officials.

Empirically, the task of assessing whether administrative courts decide cases differently from civil courts presents several challenges. The first challenge, previously described, is due to the difficulty of finding similar cases that end up in one court or the other. The second is that the legal rules that apply to both cases must be similar as well-otherwise, the outcomes of the cases would not necessarily be comparable, as they could be due to the application of different legal rules. The third challenge is that there may be potential identification issues arising from problems of selection bias. For instance, if patients with stronger claims are more likely to go to one type of court, or if patients harmed in public hospitals have a different propensity to appeal to the SSC than patients harmed in private hospitals, an observed relationship between case outcomes and type of court would not necessarily mean that courts decide differently. ${ }^{15}$

The quantification of noneconomic damages in medical malpractice cases in Spain provides a nice setting for assessing how courts award this type of damages. Medical accidents are similar, whether they take place in public or private hospitals. The legal

${ }^{15}$ A randomized experiment that would randomly assign cases to either administrative or civil courts would overcome this problem. 
rules to be applied are in practice the same. Noneconomic damages should be attributed essentially on the basis of the level of harm and age of the plaintiff. These are observable case characteristics that can be controlled for in the empirical analysis. Moreover, given the setting examined here (in which compensation for loss of income is excluded), any potential self-selection of patients into one type of hospital should not matter for the analysis. It would make a difference if the analysis were on economic damages and, for instance, richer patients self-selected into one type of hospital and these patients received higher compensation for loss of income. But our analysis is of noneconomic damages and these concerns do not arise.

In a fair and equitable legal system, courts should not award significantly different noneconomic damages in administrative and civil cases with similar characteristics (i.e., considering variables such as age and injury severity level). Even if there were differences in the types of patients going to public and private hospitals, or even differences between private and public hospitals, this should not matter for this analysis precisely because the focus is on noneconomic damages. The separation of jurisdictions, however, is responsible for several possible problems. One potential problem might be that, because there is a distinction between civil and administrative jurisdictions, damages might be different, which goes against the principle of equality granted by the Constitution (Gómez-Pomar and Sánchez Álvarez 2006). Opponents of the current separation of jurisdictions argue that courts award damages differently depending on whether the court adjudicating the case is civil or administrative. Nevertheless, extensive empirical evidence on this claim is virtually nonexistent.

Why would medical malpractice noneconomic damages be different in civil and administrative cases? The main difference between these cases is the identity of the defendant: the state (public hospitals) in administrative cases and private parties (private hospitals and practitioners) in civil cases (Amaral-Garcia and Garoupa 2015). Courts might consider that, when the state is liable, the compensation awarded to the plaintiff should be higher, as a form of punishment for the poor health care provided with the taxpayers' money. Courts might also take into account that the state has vast powers and influence. However, courts might also take into account two additional factors when setting compensation: plaintiff's future medical treatments, should these be needed, could be provided in public hospitals; and damages will be paid by the taxpayers. These two arguments might encourage administrative courts to set lower compensation amounts. Moreover, administrative judges may tend to be deferential to the state and have more difficulties in setting damages that are comparable 
to those imposed by their civil counterparts. Judges are civil servants and their employer is the state. Hence, they might be more lenient in cases in which the state is the defendant. With respect to civil decisions, if civil courts believe that private hospitals have deep pockets, they might award higher damages. Therefore, if differences in noneconomic damages exist, it is not clear in which type of decisions we should expect higher payouts.

Finally, and considering that there is no general guidance on how courts set noneconomic damages in Spain, it would be a natural consequence that judges' decisions in different court systems are not consistent or uniform in terms of noneconomic damages quantification. Spanish judges start by following a career as a generalist judge and they can then specialize in administrative law. ${ }^{16}$ On the one hand, administrative and civil judges have similar career paths: both are career judges and, as is typically the case with career judiciaries, judges are initially appointed to junior positions and promoted to senior positions at later stages (Garoupa and Ginsburg 2012); in order to become a judge, a prospective judge must take a national exam; for those approved, training at the judicial school will follow; and, finally, judges are then appointed for life. On the other hand, the types of cases that administrative and civil judges decide are different. Hence, it is not a straightforward matter to predict whether civil judges would award noneconomic damages differently than administrative judges.

\section{Medical Malpractice in Spain}

\section{The Spanish Legal System and the SC}

There is no specific law that regulates the physician-patient relationship in Spain. Essentially, it is the type of healthcare provider at which the medical injury takes place that determines the jurisdiction in which the case can be tried (Amaral-Garcia 2015b; Amaral-Garcia 2017; Amaral-Garcia and Garoupa 2015; Arroyo and Yágüez 2013; Ferrara et al. 2013; Gómez-Pomar 2001; Koch 2011; Martín-Casals et al. 2003). Therefore, a patient suffering harm in a public hospital must file a claim in the administrative jurisdiction, while a patient harmed in a private hospital must turn to the civil jurisdiction. ${ }^{17}$ According to the law on the books, one might think that the two separate subsystems impose different

${ }^{16}$ For more on specialized courts see, for example, Baum 2011, Nutting 1955 , Revesz 1990, Dreyfuss 1990, Bell 2007, Amaral-Garcia 2015 a.

17 This is also considerably different than what happens in the U.S. Spanish judges specialize in administrative or civil law, but they follow similar career paths (Garoupa et al. 2012). 
procedures on similar problems within the same system, which is actually common in some civil law tradition countries with a national public health system. Instead, case law shows that, in practice, medical malpractice cases are similar in terms of legal procedure, which makes these cases comparable. Courts effectively apply a liability rule based on fault.

The burden of proof in both types of cases lies with the patient, who needs to prove fault and causation. A reversal of the burden of proof may be granted, but only in exceptional cases. Judges make all medical malpractice decisions in Spanish courts and there are no informational asymmetries between administrative and civil judges. ${ }^{18}$ Unlike the U.S. SC, the SSC has no control over its docket, and appeals are supposed to be of general importance and have reference to some relevant legal controversy (Garoupa et al. 2012). The SSC's Administrative Section will decide appealed cases from the administrative jurisdiction and the Civil Section will decide appealed cases from the civil jurisdiction. The number of justices in each section is determined by law (Organic Law No. 6/1985 [LOPJ]). In terms of appointment and retirement, both types of justices are subject to the same rules. The same holds for the assignment of cases to the justice rapporteur, ${ }^{19}$ who writes the opinion of the panel and is assigned randomly (Garoupa et al. 2012; Organic Law No. 6/1985 [LOPJ]; Amaral-Garcia and Garoupa 2015). However, and as described above, administrative and civil judges have different legal specializations. By the time they are appointed to the SSC, they have spent a significant part of their careers deciding different types of cases.

\section{Quantification of Damages}

As Spanish law states, lower courts should set the amount of compensation due, but the SSC can modify the amount granted by lower courts if there is evidence that the previously set amount was unreasonable. Moreover, the SSC sets the amount of damages in cases where the lower courts refuse compensation and the decision is reversed on appeal. Considering that "judges have professional and reputational interests in avoiding having their damage awards adjusted on appeal" (Eisenberg and Heise 2011), we

${ }^{18}$ In the U.S., asymmetric information between judges and juries might play a role in setting damages (Eisenberg and Heise 2011).

${ }^{19}$ All members of each section can be the judge rapporteur in a particular decision. The judge rapporteur is the justice who writes the opinion. This justice will prepare the case, review the applicable legislation and case law, and propose a decision, to which all members must agree (Garoupa et al. 2012). 
should see only small differences, if any, between the quantification of damages by lower courts and by the SSC.

Spanish courts also allow patients to recover damages due to loss of a chance (Luna Yerga 2005). In medical malpractice cases, loss of a chance is typically alleged by patients who received a delayed diagnosis that diminished the patient's likelihood of recovery. For this reason, awards are necessarily lower. The court will estimate the probability of recovery in the event that the doctor had not been negligent and use this probability to assess the final amount of compensation. There is more uncertainty involved with respect to the overall compensation amount, in the sense that first a calculation must be made of the harm and, subsequently, of the probability of recovery.

Quantifying damages is difficult and requires that judges make several assumptions. In medical malpractice cases, judges are essentially asked to compute a value for an irreplaceable commodity, namely, health (or even life). Judges are aware that the patient should be fully compensated (Ley 30/1992; Arts. 1106 and 1902, Civil Code), but no guidance is provided on how damages should be calculated. ${ }^{20}$ To evaluate the patient's health status, medical experts' reports can be used (Arroyo and Yágüez 2013). Moreover, both civil and administrative judges have access to previous courts' decisions and how much compensation was awarded. However, when inspecting SSC's medical malpractice decisions, we see that, typically, both Spanish lower courts and SSC decisions cite previous cases decided by the same types of courts. Therefore, administrative decisions only cite administrative decisions and civil decisions only cite civil decisions. ${ }^{21}$

Spanish judges can rely on scheduled damage tables that were created to standardize compensation to the victims of road traffic accidents (Pintos Ager 2000; Royal Legislative Decree 8/2004, October 29; Ramos González and Luna Yerga 2004). These tables have different entries for the level of harm, age of the victim, and family relationship between the victim and the person requesting damages, which are essentially the only case characteristics considered when quantifying damages. When put together, these case characteristics result in a final euro amount. This should avoid, or at least reduce, litigation challenging the compensation provided by car insurance companies. Soon judges started using these tables to quantify damages in other areas of the law, limiting discretion. All in all, more volatility in payouts may also arise if some

${ }^{20}$ This is true for several countries. See Bovbjerg et al. (1989) for the U.S. and Chang et al. (2017) for Taiwan.

${ }^{21}$ Citation practices are different from common law: they are rare, specific, only made when needed, typically to complement a statute or code. 
judges use scheduled damages while others do not, which can be expected because of the lack of general guidance on how to compute damages.

To add to the lack of a general rule on the quantification of damages, judges are even free to choose between a per-diem or a lump-sum amount, although the SSC is extremely reluctant to award per-diem damages (ROJ-STS-3429/208 (27.06.2008)).

\section{Dataset and Descriptive Statistics}

The dataset for this analysis consists of 366 decisions. These are all medical malpractice cases decided by the SSC ${ }^{22}$ from 2006 through 2010 in which a judgment regarding the evidence of medical malpractice was made. ${ }^{23}$ Several variables of interest are collected for each decision, namely: the SSC Section that decided the case; if compensation was awarded to the plaintiff; the euro amount of noneconomic damage awards; the lower court outcome; whether the case involved a loss of a chance claim; whether scheduled damages tables were used; which party appealed to the SSC; the injured patient's sex; the injured patient's age group; and the patient's level of harm.

In order to categorize the severity of the injury, and consistent with previous literature (Bovbjerg et al. 1989), the scale provided by the U.S. National Association of Insurance Commissioners (NAIC) is used. The original scale divides the level of harm into nine levels: emotional only, temporary-insignificant, temporaryminor, temporary major, permanent minor, permanent significant, permanent major, permanent grave, and death. In my dataset, almost no cases involve the lowest level of injury severity, especially considering that among cases with a damages awardonly seven cases with a positive payout-had an emotional or temporary injury (whether insignificant, minor, or major). Therefore, I grouped these three levels of harm within a new and single level of injury severity: temporary/emotional.

Additionally, to have a consistent measure, I grouped together what NAIC categorizes as permanent minor and permanent significant levels of injury in the category permanent minor/significant; and as permanent major and permanent grave in the category

${ }^{22}$ SSC decisions are generally available to researchers. The same does not hold for lower court decisions. Therefore, trying to analyze lower court decisions would result in a biased sample of cases. In many other countries, some courts' decisions are available, also at the SC level. Often times these cases are a (biased) sample of the cases decided (e.g., the most controversial or those that judges consider to be more important).

23 There were no relevant changes in medical malpractice cases that the SSC decided in more recent years. 
permanent major/grave. The description of the harm is very similar for the injury levels that are now combined.

\section{Data Description}

Table 1 provides summary statistics for cases decided by the Administrative Section of the SSC (columns [1] and [2]) and by the Civil Section (columns [3] and [4]). Column (5) shows the ttest for the sample mean difference between administrative and civil cases. There are statistically significant differences in some characteristics, which point to the importance of including these variables in the regressions.

Damages were awarded in approximately half of the cases in both sections: 47 percent of administrative and 49 percent of civil cases (difference in means is not statistically significant, $t$ test $=0.36$ ). Civil cases take on average longer to be decided (difference in means is statistically significant, $t$-test $=21.57$ ). In both systems, medical malpractice cases most often involve obstetrics/gynecology, neurology, neurosurgery, and orthopedics (the difference in means of each of these variables not statistically significant). These specialties together account for almost half of the cases. Patient characteristics are quite similar in both sections: approximately half are male (52 percent, difference in means not statistically significant) and the vast majority are adult/elderly (73 percent in the Administrative Section and 80 percent in the Civil Section, with the difference in means not statistically significant), with considerably fewer cases involving newborns (19 percent in the Administrative Section and 13 percent in the Civil Sectiondifference in means not statistically significant, $t$-test $=-1.33$ ). Plaintiffs claim loss of a chance doctrine in almost 10 percent of cases reaching both sections, and scheduled damages were used in approximately 20 percent of cases. The SSC usually agrees with the lower court decisions: the agreement rate is 79 percent for administrative cases and 86 percent for civil cases (difference in means not statistically significant, $t$-test $=-1.53$ ). There are only five cases in which a per-diem payout was awarded, and in all of these cases the amount of compensation had been set by lower courts (which supports the claim that the SSC is reluctant in attributing per-diem payouts). In cases with compensation, the average amount of noneconomic damages is higher for administrative cases (232,408 euros) than for civil cases (156,632 euros). However, this does not take into account the level of harm suffered by the patient, which is a crucial variable for the quantification of noneconomic damages.

Table 2 provides information on the total number of cases decided by the Administrative and Civil Sections of the SSC, 


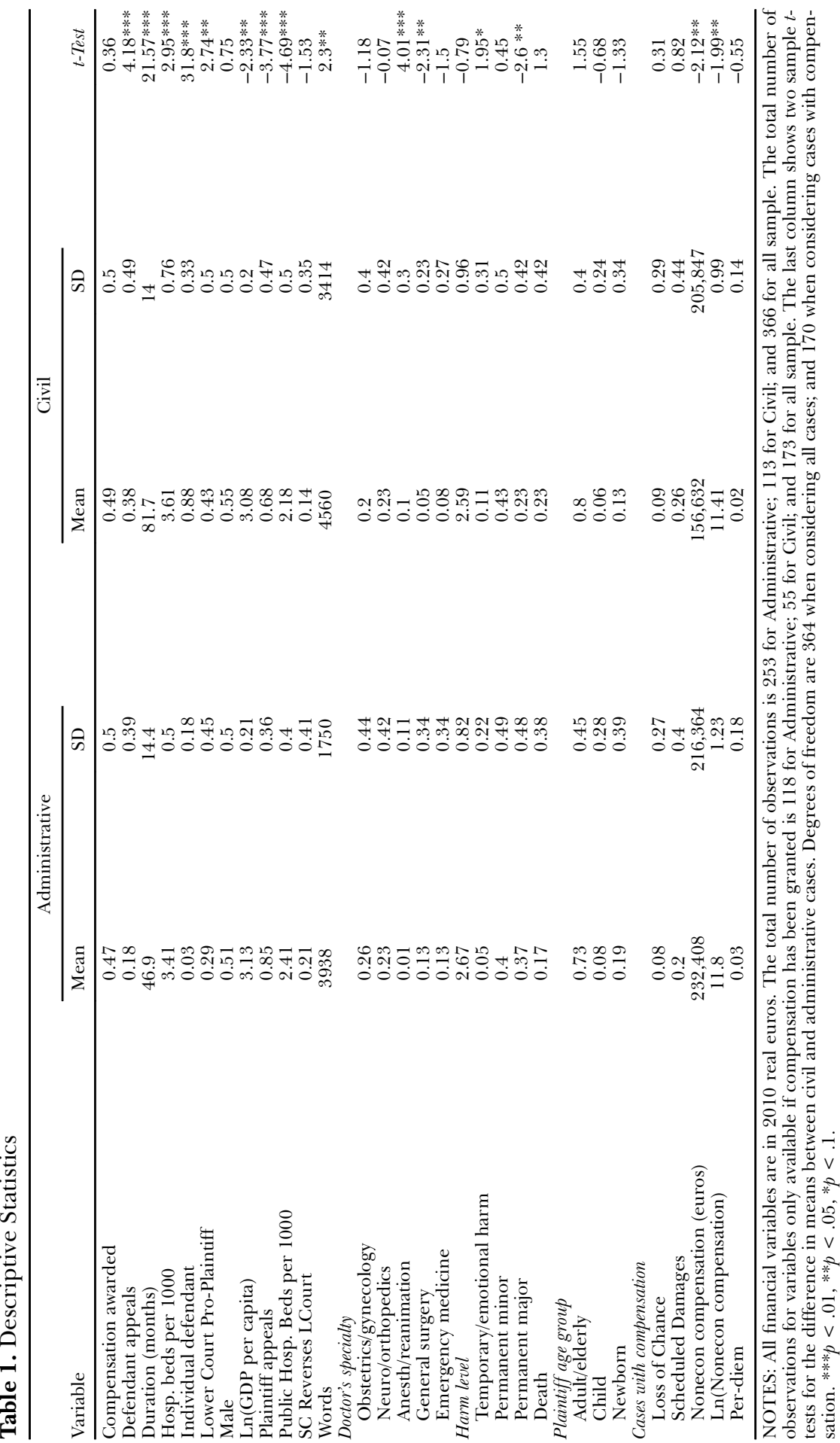


Table 2. SC Decisions on Medical Malpractice (Paid vs. Unpaid, by Level of Harm)

\begin{tabular}{llccccc}
\hline & & $\begin{array}{c}\text { Temporary/ } \\
\text { emotional }\end{array}$ & $\begin{array}{c}\text { Permanent } \\
\text { minor }\end{array}$ & $\begin{array}{c}\text { Permanent } \\
\text { major/grave }\end{array}$ & Death & Total \\
\hline Adm. & Paid & 2 & 46 & 55 & 15 & 118 \\
& Unpaid & 11 & 56 & 39 & 29 & 135 \\
& Percentage paid (\%) & 15.4 & 45.1 & 58.5 & 34.1 & 46.6 \\
Civil & 5 & 22 & 17 & 11 & 55 \\
& Paid & 7 & 26 & 9 & 15 & 57 \\
& Unpaid & 41.7 & 45.8 & 65.4 & 42.3 & 49.1 \\
\hline
\end{tabular}

NOTES: The total number of decisions at the Civil Section was 113. However, in one case the patient did not provide information on the harm suffered. For that reason, we only have 112 decisions when considering decisions by level of harm.

according to the level of harm: 52 percent involved the most severe levels of harm. The Civil Section analyzed a higher proportion of cases involving death while the Administrative Section decided a higher proportion of cases involving permanent major/grave injuries. In both sections, the proportion of cases involving zero payouts was quite similar (approximately 50 percent). Approximately 60 percent of the claims involving a permanent major harm received compensation, followed by 45 percent of permanent minor cases and 37 percent of death cases.

Figure 1 presents the distribution of noneconomic damages. As is usual in awards data, there is a substantial fraction of zero observations and a skewed positive outcome (commonly known as the "Zeros Problem"; see Eisenberg et al. 2015).

Descriptive statistics for positive payout outcomes are provided in Table 3. Claims involving the most severe levels of harm (permanent major injury, permanent grave injury, and death) account for 56 percent of the total number of paid claims and 84 percent of the total euro payout. In the Administrative Section these decisions account for 59 percent of paid claims and 85 percent of euro payouts while in the Civil Section these values were 53 and 82 percent, respectively. Consistent with previous empirical results, I find that patients suffering permanent grave harm are those receiving the highest amount of compensation, even compared to cases involving death. ${ }^{24}$

Figure 2 displays the box plots for payouts according to the level of harm. Although this figure represents payouts by harm level only, other variables play a role when awarding compensation. Nevertheless, some comparisons can be made at this stage, even though these are only crude. The line dividing each box denotes the median payout for each level of harm. The median for cases involving death, permanent grave injuries, and permanent minor

24 As shown in the table, the mean and median compensation amounts for death cases are higher for administrative cases. However, this table does not take into account other case characteristics that can play a role, such as age. Patient's age is a relevant variable in death cases, as damages are awarded to the family. 


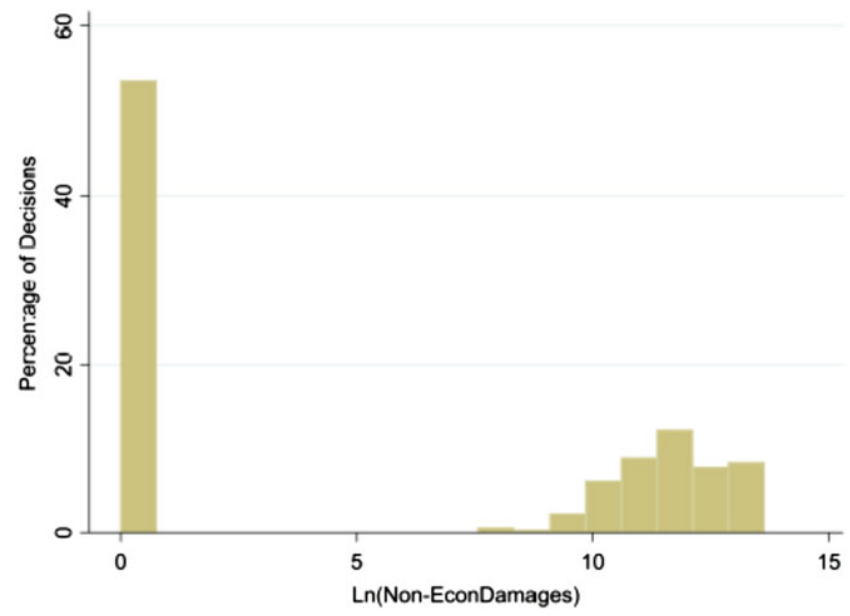

Figure 1. Distribution of Payouts.NOTE: Excludes two cases with payout higher than $€ 900,000$ (one from each section, permanent grave injury cases). [Color figure can be viewed at wileyonlinelibrary.com]

Table 3. Summary Statistics for Nonzero Payout Decisions (Noneconomic Damages, 2010€)

\begin{tabular}{rlrrrrrr}
\hline & Harm level & $\begin{array}{c}\text { No. of } \\
\text { claims }\end{array}$ & $\begin{array}{c}\text { \% of } \\
\text { total }\end{array}$ & $\begin{array}{c}\text { Total } \\
\text { payouts }\end{array}$ & $\begin{array}{c}\text { \% of } \\
\text { total }\end{array}$ & $\begin{array}{r}\text { Mean } \\
\text { payout }\end{array}$ & $\begin{array}{r}\text { Median } \\
\text { payout }\end{array}$ \\
\hline Adm & Temp. emot. & 2 & 1.7 & 40,120 & 0.15 & 20,060 & 20,060 \\
& Perm. minor & 46 & 39 & $4,176,018$ & 15.2 & 90,783 & 58,950 \\
& Perm. major & 22 & 18.6 & $4,960,693$ & 18.1 & 225,486 & 200,706 \\
& Perm. grave & 33 & 28 & $15,456,607$ & 56.4 & 468,382 & 472,396 \\
& Death & 15 & 12.7 & $2,794,094$ & 10.1 & 186,273 & 166,024 \\
& All levels & 118 & 100 & $27,427,532$ & 100 & 232,054 & 169,932 \\
Civil & Temp. emot. & 5 & 9.8 & 164,707 & 2.1 & 32,941 & 29,609 \\
& Perm. minor & 19 & 37.2 & $1,239,869$ & 15.5 & 65,256 & 52,403 \\
& Perm. major & 6 & 11.8 & $1,445,600$ & 18.1 & 240,933 & 233,639 \\
& Perm. grave & 10 & 19.6 & $4,214,634$ & 52.8 & 421,463 & 420,474 \\
& Death & 11 & 21.6 & 923,438 & 11.6 & 83,949 & 83,012 \\
& All levels & 51 & 100 & $7,988,248$ & 100 & 156,632 & 83,012 \\
\hline
\end{tabular}

injuries is higher in the Administrative Section. The median for permanent major injuries and temporary/emotional injuries is higher in the Civil Section. For both sections, the highest dispersion is present for cases involving a permanent grave injury. Awards could be as low as $€ 44,273$ and as high as $€ 1,080,000$ in the Administrative Section; and as low as $€ 56,892$ and as high as $€ 999,369$ in the Civil Section. The remaining injury levels have higher volatility if reaching administrative courts. ${ }^{25}$ Moreover, it seems that appealed cases involving death receive lower payouts in the civil

${ }^{25}$ Loss of a chance cases are excluded. Temporary/emotional cases are excluded from these considerations as well, given that very few cases of this type received a positive payout. 


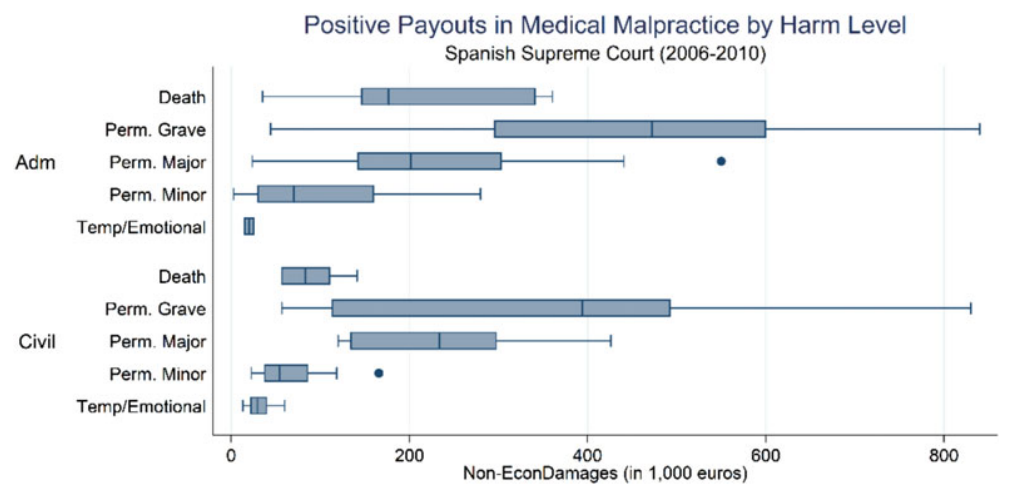

Figure 2. Payouts per Harm Level.NOTE: Excludes loss of a Chance and two cases with payout higher than $€ 900,000$ (one from each section, permanent grave injury cases). [Color figure can be viewed at wileyonlinelibrary.com]

jurisdiction: the median payout in the Administrative Section $(€ 176,850)$ is higher than the maximum in the Civil Section $(€ 141,170)$.

\section{Methodology and Results}

The first part of the empirical analysis assesses if there are any case characteristics that might have an impact on the probability of the SSC awarding compensation. ${ }^{26}$ In the second part of the empirical analysis, I assess noneconomic awards. If noneconomic damages were set fairly, there should be horizontal equity in payments with respect to the level of harm. ${ }^{27}$ In other words, patients suffering similar injuries should receive comparable payouts (some case-specific characteristics might play a role, which makes it very unlikely to find exactly equal compensation amounts). Therefore, plaintiff's sex, whether or not the suit is brought in civil courts vs. administrative courts, and whether the plaintiff comes from poorer regions or richer regions should have no impact on compensation amounts. However, the tort system should provide vertical inequity: patients suffering higher levels of injury should receive higher noneconomic damages than patients suffering lower injury levels.

One might worry that administrative cases may be different from civil cases in terms of characteristics that cannot be

${ }^{26}$ No claim will be made with respect to courts' ability to make correct decisions, as it is impossible to have such a variable in the dataset. Amaral-Garcia and Garoupa (2015) offer some reasons to rely on SC decisions as those closest to a correct decision.

27 The tort system can have many different objectives, not simply that of horizontal equity (Avraham 2006). 
controlled for or that there might be a potential selection effect. Several steps were undertaken to address this possibility. First, Kolmogorov-Smirnov tests for the equality of distribution of cases that arrive at each section of the SSC according to observable characteristics were performed, ${ }^{28}$ and no statistically significant differences were found. This is reassuring as it points to the similarity of cases reaching both sections of the SSC, making comparisons meaningful. Second, if one believes that only the most difficult cases are appealed to the SSC, then we should not see a high frequency of cases with the same outcome at each step of the litigation process. Third, appeals can be filed by the plaintiff or the defendant, and there is the presumption that state lawyers are expected to appeal up to the SSC while out-of-court settlements are virtually not allowed (Amaral-Garcia and Garoupa 2015). Therefore, should there be a selection effect and only the most difficult cases were appealed, we would expect this to be more likely in civil cases, as the state is essentially not involved in settlements. Were this true, we should not see more than half of the civil cases that reach the SSC produce the same outcome at every step of the litigation. Fourth, the aim of this part is precisely to assess outcomes of medical malpractice cases at the SSC; it is not to explain medical malpractice suits in general. Most importantly, even if one considers that a potential selection effect might exist, it is hard to imagine that it can have a role in setting noneconomic damages when the most important characteristics (namely, age and the level of harm) are controlled for in the regression analysis.

A two-part model was estimated, as reported in Equations (la) and (1b). The first part (selection Equation (1a)) models the probability of receiving compensation, $c p$, as a binary outcome. Hence, the dependent variable $c p$ is equal to 1 if compensation was awarded and 0 if not. This equation controls for several case characteristics denoted by $X$, such as Administrative, which is equal to 1 if the decision was made by the Administrative Section and 0 if it was made by the Civil Section; Lower Court Pro-Plaintiff, which takes the value of 1 if the lower court awarded damages to the plaintiff and 0 if compensation was refused; Male, which equals 1 if the plaintiff is male and 0 if the plaintiff is female; patient's age group, which can be Newborn, Child, or Adult/Elderly; level of harm suffered (Temporary/Emotional Harm, Permanent Minor, Permanent Major/Grave or Death); Ln(GDPpc), the logarithm of regional GDP per capita in 2010 prices; and doctor's specialty

${ }^{28}$ This test allows us to compare the sample of administrative and civil cases according to different variables. For each relevant variable (e.g., level of harm, patient's age), a test is performed to check whether the distribution of administrative cases differs from the distribution of civil cases with respect to that variable. 
(Obstetrics/Gynecology, Neuro/Orthopedics, Anesth/Reanimation, General Surgery, Emergency Medicine, or other).

The second part (outcome Equation (1b)) considers only cases in which a payout was awarded $(C P=1)$ and models the amount of noneconomic damages. ${ }^{29}$ The dependent variable NonEconCp is the logarithm of noneconomic damages awarded to the plaintiff. Besides the control variables $X$ that are used to estimate the probability of receiving compensation (selection equation), the outcome equation also includes the following variables: Loss of chance, which equals 1 if the decision claimed loss of a chance doctrine and 0 otherwise; and Scheduled Damages, which equals 1 if scheduled damage tables were used to set the level of noneconomic damages and 0 otherwise.

I am particularly interested in testing whether the control variable Administrative is statistically significantly different from zero. This would be evidence that administrative courts attribute noneconomic compensation differently than civil courts, and it could not be explained by differences in the age of the patient, level of harm, gender, doctors' specialty, or any other variable that is part of the control variables (and they are already controlled for in the regression analysis).

The two-part model $^{30}$ for compensation can be written in the following way:

$$
\begin{aligned}
& f(\text { NonEconCp|X) } \\
& = \begin{cases}\operatorname{Pr}(c p=0 \mid X) & \text { if NonEconCp }=0, \\
\operatorname{Pr}(c p=1 \mid X) f(\text { NonEconCp } \mid c p=1, X) & \text { if NonEconC } p>0 .\end{cases}
\end{aligned}
$$

\section{Results}

Table 4 shows the regression results for the two-part model for three different specifications: the first includes a small number of control variables, with additional control variables being added

${ }^{29}$ As is widely recognized in the literature, this departure from the classical Tobit approach has the strength of allowing two different processes: determining the decision to award compensation and determining the compensation magnitude. Moreover, the two-part model is preferable to the Tobit since the homoskedasticity and normality hypotheses are not necessary conditions for consistency of the estimator (Cameron and Trivedi 2005).

${ }^{30}$ Let NonEconC $p$ denote noneconomic compensation attributed at the SSC, our dependent variable. Define the binary indicator $C P$ such that $C P=1$ if NonEconCp $>0$ (positive payout) and $C P=0$ if NonEconC $p=0$ (no payout). When NonEconC $p=0$, we can only observe $\operatorname{Pr}(C P=0)$. For those cases with NonEconC $p>0$, let $\mathrm{f}\left(\operatorname{NonEconC} p \mid{ }_{C P}=1\right)$ be the conditional density of NonEconCp. The outcome equation is a linear regression of the logarithm of NonEconCp on the set of explanatory variables, for those observations with $C P$ equal to one. 


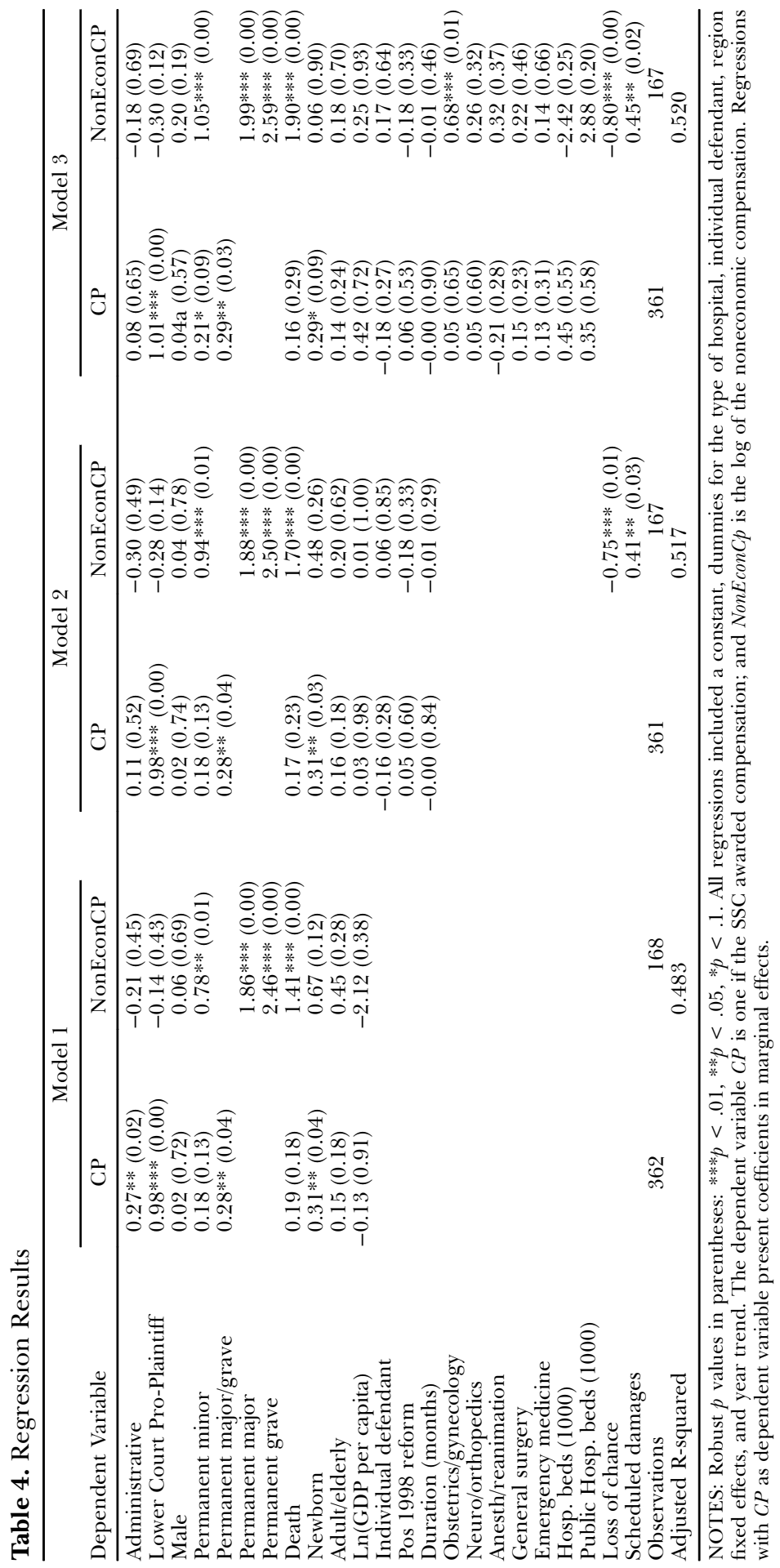


in the subsequent specifications. ${ }^{31}$ The likelihood of receiving compensation is not different for civil and administrative cases that reach the SSC: the dummy for Administrative is generally not statistically significant (except in column [1], but the coefficient is no longer statistically significant when more control variables are added). Appealing a decision in which the lower court delivered a pro-plaintiff outcome seems to increase the probability of receiving compensation, which is justified by the fact that the SSC tends to agree with the lower court in the majority of cases. As described in section "Data Description," the overall agreement rate is approximately 80 percent.

Patients suffering permanent major/grave injuries have a higher probability of receiving compensation compared to patients suffering temporary/emotional injuries (of between 28 and 29 percent higher). Cases involving injury to newborns are associated with a higher probability of receiving a positive payout (between 29 and 31 percent higher). Patient's gender has no impact on the probability of receiving compensation.

With respect to noneconomic damages, the outcome of most interest here, the first thing to notice is that the variable Administrative is never statistically significant. Therefore, there is no evidence of significant differences in noneconomic compensation amounts between the Administrative and Civil Sections of the SSC. This result is also confirmed in the matching and simulation exercises.

Cases involving permanent major injuries, permanent grave injuries, and death receive much higher amounts of noneconomic compensation in comparison with temporary/emotional injuries. Cases involving permanent grave injuries receive the highest noneconomic damages, which amounts from 430 to 490 percent more than in cases involving temporary/emotional injuries. ${ }^{32}$ Permanent major injuries follow, receiving on average from 236 to 269 percent more than the baseline group. Cases involving death receive from 151 to 246 percent more than temporary/emotional cases.

When courts consider that patients should be compensated under the loss of a chance doctrine, the award levels are considerably lower in comparison with cases that are fully compensated.

The use of scheduled damages has a statistically significant and positive impact on noneconomic payouts. This is a surprising outcome, as these tables limit the level of damages that patients can recover and tend to be seen as a way of limiting compensation

31 Columns (1), (3), and (5) present the results for the selection equation; columns (2), (4), and (6) present the results for the outcome equation.

${ }^{32}$ I use $\exp (\beta-1) \times 100 \%$ in order to obtain the exact percentage change. 
amounts. It should be noticed, however, that the vast majority of cases do not use these tables to compute damages.

\section{Robustness Check: Matching and Simulation}

Matching and simulation exercises are performed as part of a robustness check on the results. The sample of cases that are decided by the administrative and civil courts are not randomly distributed, even though there are relevant case characteristics that are being controlled for in the regression analysis. The aim of the matching is to generate two groups of patients that are comparable on various characteristics but differ on the type of court where their claim is brought. ${ }^{33}$ The idea is to approximate randomized trials as much as possible (Ho and Rubin 2011). In other words, for each case decided by administrative courts, I start by finding a statistical twin that was decided by civil courts. The aim is to pair cases that are very similar, except that one was decided in civil courts and the other in administrative courts. Only matched cases are used to estimate the effect of being decided in administrative courts. Although this procedure reduces the sample, it ensures that the compared cases are very similar in terms of observable characteristics. Finding differences in terms of outcomes would be evidence that administrative courts decide cases differently than civil courts.

Table 5 presents the results for the effect of being judged in administrative courts ${ }^{34}$ for two different outcomes: ${ }^{35}$ (1) the probability of receiving compensation (upper part of the table) and (2) the compensation amount (lower part of the table). The results show no statistically significant differences between administrative and civil courts. Hence, even when comparing only cases that are very similar but brought in different sections of the SSC, no relevant differences in outcomes are found.

Finally, a simulation exercise is performed. The simulation exercise aims at creating a counterfactual compensation under different scenarios. What we can observe is the outcome of an administrative case that was decided in administrative courts and the outcome of a civil case that was decided in civil courts. However, what would have been the outcome of an administrative case if it had been decided by civil courts? And what would have been the outcome of a civil case if it had been decided by administrative courts? The simulation exercise consists of building an artificial model given that these cases are not observed in real life. If the

\footnotetext{
33 I use propensity score matching to match administrative with civil cases.

34 This is equivalent to the average treatment effect of the treated.

35 The regressions are equivalent to those presented in Table 4.
} 
Table 5. Matching Results

\begin{tabular}{lcll}
\hline & Av Effect on Adm & s.e. & $t$ \\
\hline Probability of receiving compensation & & & \\
Specification as in Reg 1, Table 4 & 0.04 & 0.146 & 0.278 \\
Specification as in Reg 3, Table 4 & 0.04 & 0.14 & 0.29 \\
Specification as in Reg 5, Table 4 & 0.04 & 0.15 & 0.27 \\
Amount of compensation & & & \\
Specification as in Reg 2, Table 4 & 0.312 & 0.309 & 1.011 \\
Specification as in Reg 4, Table 4 & 0.312 & 0.32 & 0.976 \\
Specification as in Reg 6, Table 4 & 0.312 & 0.303 & 1.031 \\
\hline
\end{tabular}

NOTE: Bootstrapped standard errors; 1000 replications.

results of this simulated world are very different from the observed cases, it could point to the fact that courts decide cases differently.

I use the estimated model (Section Methodology and Results) to predict the counterfactual outcome for an administrative case had it been decided by the Civil Section; and to predict the counterfactual outcome of a civil case had it been decided by the Administrative Section. For each administrative and civil case, I ran 1000 simulations to compute the simulated probability of receiving compensation and, in cases where compensation was awarded, the respective simulated amount of noneconomic damages. To obtain the average simulated compensation, I calculated the mean compensation for each observation that received compensation, using the simulated outcomes per observation. Figure 3 shows the box plot for outcomes for which compensation was awarded that are observed (upper part of the figure) and simulated (lower part). In both administrative and civil cases, there is less variation for simulated cases compared to the observed ones (except for administrative cases involving temporary/emotional injuries, which is explained by the reduced number of observations). For administrative cases, median simulated payouts are higher than observed payouts, except for death cases. In other words, according to this simulation exercise, administrative cases would have had a higher median payout had they been decided by civil courts. The opposite holds for civil cases, as they would have had a lower median payout had they been decided by administrative courts.

One important conclusion is that there are no sizable differences between observed and simulated outcomes in either court. In no case is the simulated range completely outside the boundaries of the observed outcomes. As a final exercise, the distribution of noneconomic damages for simulated cases is computed and compared with observed (real) outcomes. Figure 4 provides visualizations of the marginal distribution of administrative and civil cases. ${ }^{36}$ There is essentially no difference in terms of the 

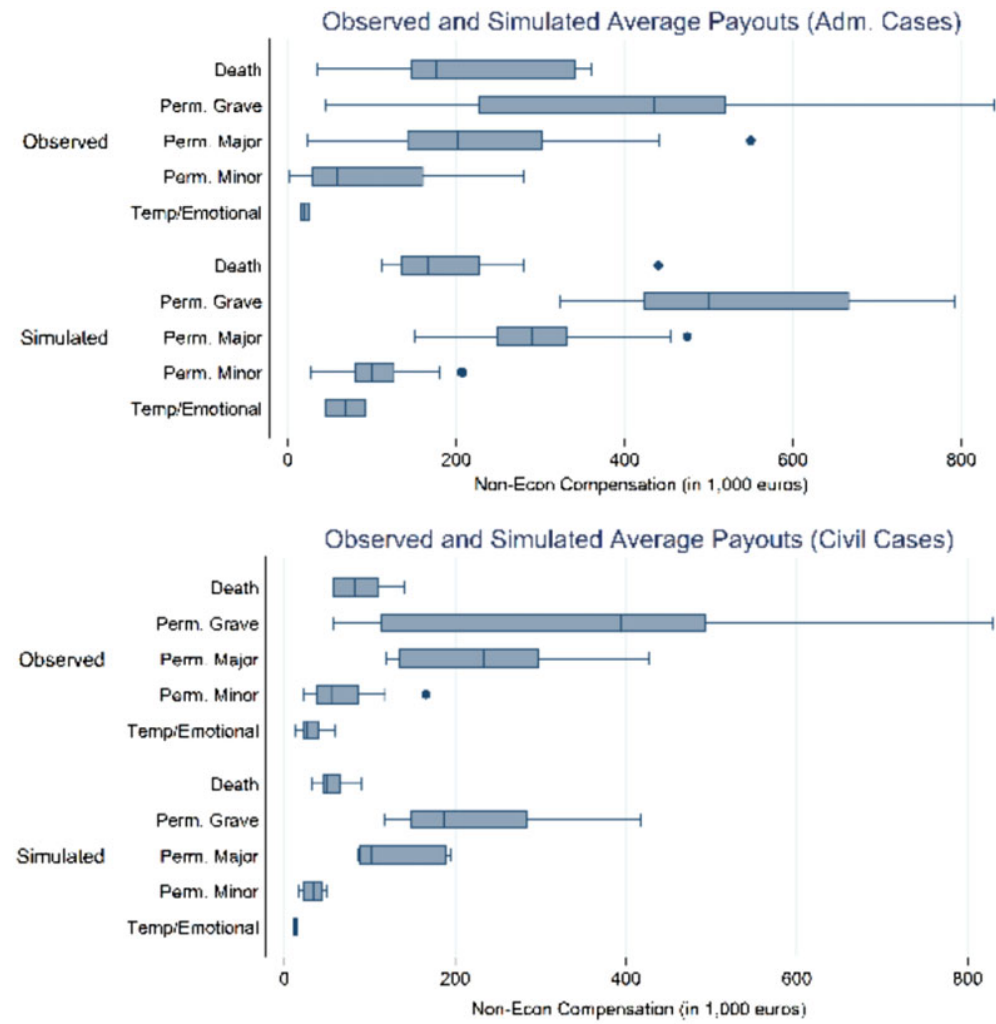

Figure 3. Payouts for Civil Observed and Simulated Outcomes-Administrative and Civil. [Color figure can be viewed at wileyonlinelibrary.com]

number of cases where compensation is refused (approximately 55 percent for both administrative observed and simulated cases, and 56 percent for civil observed cases and 55 percent for civil simulated cases). ${ }^{37}$ Therefore, the total number of administrative cases that would have received compensation if they had been decided by civil courts is equivalent to the observed number of administrative cases receiving compensation (and the same holds for civil cases, had they been decided by administrative courts). As for the distribution of cases receiving a positive payout, only small differences are found. For administrative cases, the results show evidence of a lower number of observed cases receiving medium

36 The $x$-axis corresponds to groups $0-7$ in order to have both simulated and observed distributions on the same graph. Group 0 represents cases without compensation; groups 2-4 represent low payout cases; group 5 represents medium payout; group 6 represents high payout cases; and group 7 represents cases with a very high payout.

37 There are small differences with respect to Table 1 due to a few observations that are dropped in the simulation exercise. 

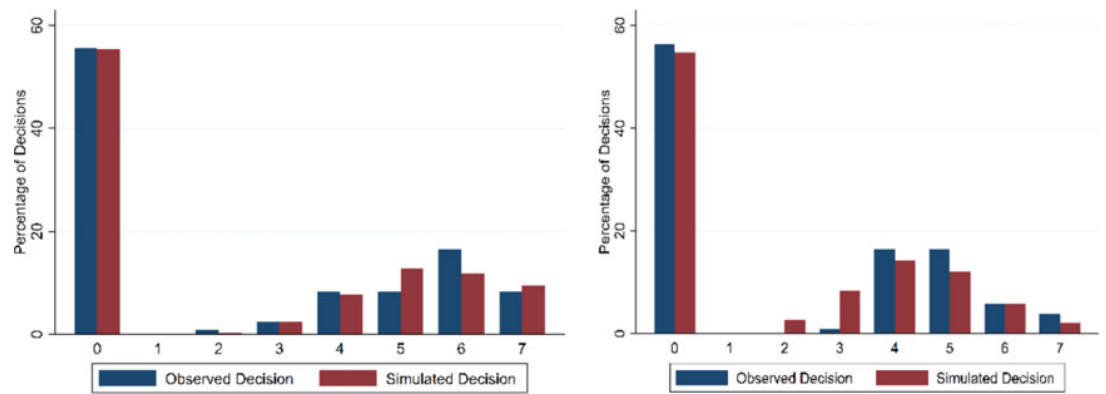

Figure 4. Distribution of Payouts: Observed and Simulated DecisionsAdministrative and Civil. [Color figure can be viewed at wileyonlinelibrary.com]

payout (group 5, 8.2 percent of cases) compared to simulated cases (12.8 percent of cases). The opposite holds for cases receiving a high payout (group 6, 16.5 percent of observed cases and 11.7 percent of simulated cases). Therefore, if administrative cases had been decided by civil courts, there would have been a slightly higher number of cases receiving medium payout and a slightly lower number of cases receiving high payout in comparison with observed outcomes. The proportion of cases receiving very high payout is slightly higher for simulated cases.

With respect to civil cases, there is a lower number of simulated cases receiving medium and high payouts (groups 4 and 5), while there is a higher number of simulated civil cases receiving low payouts (group 3).

In accordance with the results from the simulation exercises, administrative cases would not show significant differences in terms of compensation probabilities and noneconomic damages amounts in the event they had been decided by the civil jurisdiction. The same holds with respect to civil cases, had they been decided by administrative courts.

\section{Discussion}

\section{Predictors of Compensation}

The regression results show that, after controlling for several covariates, there is no statistically significant difference in the probability of receiving compensation from the Administrative or Civil Sections of the SSC. This result is confirmed by further robustness checks (matching and simulation exercises).

There is also evidence that suffering a permanent major/grave level of harm is a strong predictor of receiving compensation. Critics of the medical malpractice liability system argue that courts award compensation to patients when there is no evidence of 
negligence and that this happens mainly in cases involving a permanent disability. Recent empirical literature shows that, even if the tort system is not perfect in matching merits of claims and outcomes, negligence matters for predicting outcomes and the system is able to eliminate frivolous claims (Baker 2005; Farber and White 1991; Sloan and Hsieh 1990; Studdert and Mello 2007). Although I find that higher levels of harm are strong predictors of receiving payouts, no claims should be made with respect to the accuracy of the SSC in judging medical malpractice cases. In fact, no variable allowing us to check for negligence is available. However, it should be added that, of those cases involving a permanent major/grave level of harm, the SSC refused compensation in approximately one-third of them. As for cases involving death, of 44 administrative cases (and 26 civil cases), compensation was denied in 29 (and 15) of them (Table 2). Therefore, suffering a high severity injury is not a sufficient condition to receive compensation.

When considering the age of the injured patient, there is evidence that newborns are more likely to receive compensation. Cases involving newborns generally involve a permanent major/ grave level of harm. The gender of the patient does not play a role, so judges do not make a distinction between male or female patients.

Cases in which the lower court delivered a pro-plaintiff outcome are more likely to receive compensation from the SSC. This result is in line with the fact that the majority of appeals in civil law countries fail (Shavell 2010). In other words, the SC can reverse outcomes from lower courts, but it tends to confirm previous outcomes in the majority of cases (the overall agreement rate at the SSC was 82 percent for medical malpractice cases). Therefore, the likelihood of having a pro-plaintiff outcome is higher if the lower court delivered a pro-plaintiff outcome as well, precisely due to the high agreement rate.

Finally, other case characteristics do not have a significant impact on the probability of receiving compensation. For instance, there is no relevant difference between patients residing in poorer or richer regions, or between larger or smaller hospitals.

\section{Amount of Noneconomic Damages}

I now turn to a discussion of the amount of noneconomic damages in medical malpractice cases reaching the SSC, which is the main focus of this article. Given the separation of jurisdictions in Spain, the most interesting question is whether these separate jurisdictions are able to achieve similar results, or whether there are significant differences between administrative and civil 
decisions. What can be said about the way that courts attribute noneconomic damages? Do courts treat parties differently? Does it matter if the state is the defendant?

A consistent result that emerges from the empirical analysis is that there is no evidence of significant differences between noneconomic compensation amounts for cases reaching the Administrative and Civil Sections of the SSC, after controlling for observable case characteristics. Therefore, there is no evidence that the state is treated differently. This is an important result, in particular considering the debate on the separation of jurisdictions in civil law tradition countries. Having separate courts in which to sue the state does not necessarily mean that noneconomic damages will be different and that victims should refrain from bringing claims against the state. Yet, this result does not imply that administrative and civil courts award noneconomic damages in medical malpractice cases in a consistent way. It does show, however, that there is no evidence that these courts decide cases differently. Administrative and civil judges might set similar noneconomic damages for different reasons. One possibility might be that, in spite of the specialization of administrative judges, the quantification of damages in medical malpractice cases does not pose relevant differences according to whether the medical accident took place in a private or public hospital. From a legal perspective, and according to the Spanish legal system, these cases are similar. Another possibility is that, even though judges do not cite cases from other courts, they are aware of the decisions made in other courts. As explained previously, in Spain there are different courts and judges can specialize in administrative law. Still, the career that judges follow is similar and it is natural that a judge starts by deciding civil cases and then goes on to decide administrative cases. Finally, another possibility is that, in both courts, there may be a random component to how judges award noneconomic damages. Precisely because this holds in both civil and administrative decisions, there are no significant differences between them. ${ }^{38}$

Also consistent with previous literature, the results show that patients suffering permanent major and permanent grave levels of harm are those receiving higher payouts, even compared to cases involving death. Therefore, a vertical inequity in payments according to the level of harm is present in our data, but this is

${ }^{38}$ It is not straightforward to predict what the outcome would be in countries where judges have different backgrounds. Whether these judges could reach similar outcomes is an empirical question. Still, given the legal formalities and the general lack of guidance on how to set damages, it is possible that they would also reach similar outcomes. 
reasonable: patients suffering more serious injuries should be those receiving higher awards. Nevertheless, it is hard to make judgments in terms of the horizontal equity of awards. Although Figure 2 seems to point to a high dispersion of payouts by harm level, regression results do not support this. ${ }^{39}$

Similar to the results with respect to the probability of receiving compensation, other patient characteristics do not seem to play a role when setting noneconomic damages. For instance, there is no evidence of differences in awarding noneconomic damages to patients according to their gender or their region of residence. This is reassuring, as these variables should not matter for the quantification of noneconomic damages.

Another relevant question is whether the way that judges compute damages may influence how much plaintiffs receive. The results suggest that the use of scheduled damages is correlated with higher compensation amounts (see section Quantification of Damages for a description of these tables). After a closer look at the data, it is possible to identify that, out of all cases in which scheduled damages were used, only one case had the computation of damages determined by the SSC. All of the remaining cases refer to those in which lower courts awarded compensation, which means that the computation was made by these courts and not by the SSC. Few SSC cases use schedules. Moreover, the decisions that use them tend to be those involving a permanent major level of harm.

The results regarding the use of schedules do not allow us to draw conclusions with respect to the best way of computing damages: with or without schedule tables (Arlen 2000; Avraham 2006; Bovbjerg et al. 1989; Geistfeld 1995). They show that, in the reduced number of cases in which schedules were used, the amount of compensation was higher on average. The fact that courts calculate damages in a nonsystematic away in general (lack of guidance) and use different methods (use of schedule tables vs. no use of tables) might be problematic in the sense that victims cannot predict how much they can recover in terms of compensation, even by looking at similar cases.

\section{Conclusions}

Drawing on a rich dataset of appeals to the SSC, I investigated how courts award noneconomic damages in medical malpractice cases and whether it matters that the state is the defendant. First,

${ }^{39}$ Simulated results do not show striking difference with respect to observed outcomes. However, it is important to note that observed cases have a higher dispersion, as Figure 3 shows. 
I use the entire sample of cases to determine if there are case characteristics that are associated with a higher likelihood of receiving compensation. Second, I assess which factors determine the quantification of noneconomic damages. I found no significant differences between cases with and without the state as the defendant. This finding is further confirmed by matching and simulation analysis.

The findings of this article contribute to two different literatures. First, they contribute to the literature on the separation of jurisdictions, where specialized courts play a significant role, which is a common feature of civil law tradition countries (Merryman and Perez-Mordomo 2007). A concern for legal systems and society in general is that similar cases decided in different jurisdictions might be subject to different treatments and reach different outcomes. Second, the findings contribute to the empirical literature on noneconomic damages in medical malpractice cases, a topic that is poorly developed in civil law countries.

The main finding of this article has implications not only for civil law tradition countries, but also for the business of courts in general (Latour 2009). Courts decide cases that have implications for several parties and a relevant part of these cases involve the state. In this setting, harmed patients are one-shotters as they have recourse only occasionally to the courts, while both types of hospitals are repeat players as they engage in many similar litigations over time (Galanter 1974). Still, the state is more frequently the defendant than is any other party. This could give the state an advantage because compensation amounts could be set systematically lower when the state is the defendant. Moreover, judges are civil servants and could be more deferential toward the state. What this article shows is that courts do not seem to give an advantage to the state when setting noneconomic damages. If courts are trying to influence the politics of the legal system, they are doing it similarly in civil and administrative cases. The framework of the present work does not allow us to investigate this mechanism further, which can be a crucial topic for future inquiry.

The results of this work also support the existence of vertical inequality of awards by level of harm: patients suffering permanent grave and permanent major injuries receive higher awards, even compared to cases involving death. However, it is harder to draw conclusions with respect to horizontal equity of payments. The quantification of damages for physical injury and death is naturally a difficult task, but it must be made. The lack of clear and consistent ways to quantify damages can make the problem more difficult for both judges and parties taking part in the litigation process. 
Having different jurisdictions deciding similar cases is not a unique particularity of the Spanish legal system. The same holds with respect to specialized courts that decide cases involving the state. There are arguments that point to a possible pro-state bias on the part of these courts along with different treatments of cases across from different jurisdictions, which could discourage injured patients from filing a claim against the state. What the results in this article show is that, despite having different jurisdictions for these types of claims, the outcomes achieved in terms of noneconomic damages in medical malpractice cases appealed to the SSC do not differ significantly. There is some variability in noneconomic damages, but this is not specific only to administrative or civil courts: variability is found in both courts. However, the fact that administrative and civil decisions do not differ in significant ways does not imply that noneconomic damages are being set in an equitable and fair manner by both types of courts.

Finally, the arguments justifying the existence of specialized courts to judge certain types of cases do not seem to hold for medical malpractice cases involving public hospitals. There are no particularities in medical malpractice cases involving the state that make them significantly different from cases involving private parties and that require different courts and specialization to judge them. Further empirical research on other legal systems and types of courts would be a positive contribution to the debate on the separation of jurisdictions. What this article shows is that this separation per se does not imply that courts reach different outcomes when the state is one of the parties in the litigation. Considering the role of the state and courts, it would be interesting to investigate other types of cases, such as taxation and immigration (see Hamlin (2014), Ryo (2018), Sterett (1997)). However, these cases pose the obvious challenge of dealing with issues that are particular to the role of the state, which means that they would not have a counterpart with which to compare them. In the current era of increasing juridification and judicialization of modern life (Ginsburg 2009; Hirschl 2006; Hirschl 2011), it is crucial for society that citizens and other parties litigating with the state are not disadvantageously treated. Continuing research on how courts decide cases and influence policy will play a relevant role in our understanding of the business of courts and of the design of different legal systems.

\section{References}

Amaral-Garcia, Sofia (2015a) "Administrative Courts," in Backhaus, J., ed., Encyclopedia of Law and Economics. New York, NY: Springer.

- (2015b) "Daño moral derivado de lesiones," in Gómez-Pomar \& Marin Garcìa, eds., El Daño Moral y su cuantificación. Madrid: Bosch. 393-433. 
- (2017) "El Tribunal Supremo y los casos por negligencias médicas en España," 151 Papeles de Economía Española 21-32.

Amaral-Garcia, Sofia \& Nuno Garoupa (2015) "Do Administrative Courts Favor the Government? Evidence from Medical Malpractice in Spain," 6 European J. of Tort Law 241-59.

Arlen, Jennifer (2000) “Tort Damages," in Bouckaert, B. \& G. De Geest, eds., Encyclopedia of Law and Economics. Cheltenham: Edward Elgar. 682-734.

Arroyo, María C. \& Ricardo de Ángel Yágüez (2013) "Medical Responsability and Liability in Spain," in Ferrara, S. D., R. Boscolo-Berto, \& G. Viel, eds., Malpractice and Medical Liability: European State of the Art and Guidelines. Springer.

Avraham, Ronen (2006) "Putting a Price on Pain-And-Suffering Damages: A Critique of the Current Approaches and a Preliminary Proposal for Change," 100 Northwestern Univ. Law Rev. 87-120.

- (2017) "Estimating Pain-And-Suffering Damages," in The Oxford Handbook of Law and Economics. Oxford, UK: Oxford Univ. Press.

Baker, Tom (2005) "Reconsidering the Harvard Medical Practice Study Conclusions about the Validity of Medical Malpractice Claims," 33 J. of Law, Medicine E Ethics 501514.

Baum, Lawrence (2011) Specializing the Courts. Chicago: Univ. of Chicago Press.

Bell, John (2007) "Administrative Law in a Comparative Perspective," in Orucu, E. \& D. Nelken, eds., Comparative Law: A Handbook. Oxford: Hart Publishing.

Bielen, Samantha, Wim Marneffe, \& Lode Vereeck (2015) "An Empirical Analysis of Case Disposition Time in Belgium," 11 Rev. of Law E Economics 293-316.

Bovbjerg, Randall R., Frank A. Sloan, \& James F. Blumstein (1989) "Valuing Life and Limb in Tort: Scheduling Pain and Suffering," 83 Northwestern Univ. Law Rev.

Cameron, A. Colin \& Pravin K. Trivedi (2005) Microeconometrics - Methods and Applications. New York, NY: Cambridge Univ. Press.

Cane, Peter (2011) "Administrative Law," 5th ed. Oxford: Oxford University Press.

Chang, Yun-chien, Theodore Eisenberg, Tsung Hsien Li, \& Martin T. Wells (2017) "Pain and Suffering Damages in Personal Injury Cases: An Empirical Study," 14 J. of Empirical Legal Studies 199-237.

Comandè, Giovanni (2009) "Doing Away with Inequality in Loss of Enjoyment of Life," in Ward, John O. \& Robert J. Thornton, eds., Personal Injury and Wrongful Death Damages Calculations: Transatlantic Dialogue, Vol. 91. Bengley, UK: Emerald Group Publishing Limited.

Cooter, Rob (1988) "Punitive Damages for Deterence: When and how Much," 40 Alabama Law Rev. 1143-96.

Croley, Steven P. \& Jon D. Hanson (1995) "The Nonpecuniary Costs of Accidents: Pain-And- Suffering Damages in Tort Law," 108 Harvard Law Rev. 1785-917.

Cross, Frank B. \& Dain C. Donelson (2010) "Creating Quality Courts," 7 J. of Empirical Legal Studies 490-510.

Dari-Mattiacci, Giuseppe, Nuno M. Garoupa, \& Fernando Gómez-Pomar (2010) "State Liability," 18 European Rev. of Private Law 773-811.

Dreyfuss, Rochelle C. (1990) "Specialized Adjudication," Brigham Young Univ. Law Rev. $377-441$.

Eisenberg, Theodore \& Michael Heise (2011) "Judge-Jury Difference in Punitive Damage Awards: Who Listens to the Supreme Court?" 8 J. of Empirical Legal Studies 325-57.

Eisenberg, Theodore, Thomas Eisenberg, Martin Wells, \& Min Zhang (2015) "Addressing the Zeros Problem: Regression Models for Outcomes with a Large Proportion of Zeros, with an Application to Trial Outcomes," 12 J. of Empirical Legal Studies 161-86.

Eisenberg, Theodore, Talia Fisher, \& Issi Rosen-Zvi (2011) "Israel's Supreme Court Appellate Jurisdiction: An Empirical Study," 96 Cornell Law Rev. 693-726.

Farber, Henry S. \& Michelle J. White (1991) "Medical Malpractice: An Empirical Examination of the Litigation Process," 2 The RAND J. of Economics 199-217. 
Ferrara, Santo D., Rafael Boscolo-Berto, \& Guido Viel (2013) "Malpractice and Medical Liability: European State of the Art and Guidelines," in Malpractice and Medical Liability: European State of the Art and Guidelines. Heidelberg: Springer.

Flatscher-Thöni, Magdalena, Andrea M. Leiter, \& Hannes Winner (2013) "Pricing Damages for Pain and Suffering in Court: The Impact of the Valuation Method," 10 J. of Empirical Legal Studies 104-19.

Flatscher-Thöni, Magdalena \& Leiter, Andrea M. \& Winner, Hannes (2015) "Are Pain and Suffering Awards (Un)Predictable? Evidence from Germany," Working Paper.

Galanter, Marc (1974) "Why the 'Haves' Come out Ahead: Speculations on the Limits of Legal Change," 9 Law छ Society Rev. 95-160.

Garoupa, Nuno \& Tom Ginsburg (2012) "Hybrid Judicial Career Structures: Reputation Vs. Legal Tradition," 3 J. of Legal Analysis 1-38.

Garoupa, Nuno \& Carlos Gomez-Liguerre (2011) "Efficiency of the Common Law," 100 Ius Commune Europaeum: Legal Origins.

Garoupa, Nuno, Marian Gili, \& Fernando Gómez-Pomar (2012) "Political Influence and Career Judges: An Empirical Analysis of Administrative Review by the Spanish Supreme Court," 9 J. of Empirical Legal Studies 795-826.

Garoupa, Nuno M., Gomez-Pomar, \& Veronica Grembi (2013) "Judging under Political Pressure: An Empirical Analysis of Constitutional Review Voting in the Spanish Constitutional Court," in J. of Law, Econ. E Organization, Vol. 29. 513-34.

Geistfeld, Mark (1995) "Placing a Price on Pain and Suffering: A Method for Helping Juries Determine Tort Damages for Nonmonetary Injuries," 83 California Law Rev. 773.

Ginsburg, Tom (2009) "The Judicialization of Administrative Governance: Causes, Consequences and Limits," in Ginsbourg, Tom \& Albert Chen, eds., Administrative Law and Governance in Asia - Comparative Perspectives. New York, NY: Routledge. 1-20.

Gómez-Pomar, Fernando (2001) "Carga de la prueba y responsabilidad objetiva" 01 InDret.

Gómez-Pomar, Fernando \& Víctor Sánchez Álvarez (2006) "El Problema de la Responsabilidad de las Administraciones Públicas en Derecho Español: la visión del análisis económico de derecho," 34 Sub Judice 27-47.

Grembi, Veronica \& Nuno M. Garoupa (2013) "Medical Malpractice in Civil Law: Some Evidence from the Italian Court of Cassation," 8 Health Economics, Policy, and Law 423-52.

Hamlin, Rebecca (2014) Let me Be a Refugee - Administrative Justice and the Politics of Asylum in the United States, Canada, and Australia. New York, NY: Oxford Univ. Press. (2016) “'Foreign Criminals,' the Human Rights Act, and the New Constitutional Politics of the United Kingdom," 4J. of Law and Courts 437-61.

Hirschl, Ran (2006) "The New Constitutionalism and the Judicialization of Pure Politics Worldwide," 75 Fordham Law Rev. 721-54.

- (2011) "The Judicialization of Politics," in Goodin, Robert E., ed., The Oxford Handbook of Political Science.

Ho, Daniel \& Donald Rubin (2011) "Credible Causal Inference for Empirical Legal Studies," 7 Annu. Rev. Law Soc. Sci. 17-40.

Karapanou, Vaia \& Louis Visscher (2010) "Towards a Better Assessment of Pain and Suffering Damages," $1 \mathrm{~J}$. of European Tort Law 48-74.

King, Joseph H., Jr. (2004) "Pain and Suffering, Noneconomic Damages, and the Goals of Tort Law," 57 SMU Law Rev.

Koch, Bernhard A. (2011) "Medical Liability in Europe - a Comparison of Selected Jurisdictions," 29 Tort and Insurance Law.

LaPorta, Rafael, Florencio Lopez-de-Silanes, \& Andrei Shleifer (2008) "The Economic Consequences of Legal Origins," $46 \mathrm{~J}$. of Economic Literature 285-332.

Latour, Bruno (2009) The Making of Law - an Ethnography of the Conseil d'Etat. Cambridge: Polity Press. 
Leiter, Andrea, Magdalena Thöni, \& Hannes Winner (2012) "Evaluating Human Life Using Court Decisions on Damages for Pain and Suffering," 32 International Rev. of Law and Economics 119-28.

Luna Yerga, Álvaro (2005) "Oportunidades Perdidas - La doctrina de la pérdida de oportunidad en la responsabilidad civil médico-sanitária", 02 InDret.

Mahoney, Paul (2001) "The Common Law and Economic Growth: Hayek Might Be Right," 30 The J. of Legal Studies 503-25.

Martín-Casals, M., J. Ribot Igualada, \& J. Solé Feliu (2003) "Medical Malpractice Liability in Spain: Cases, Trends and Developments," 10 European J. of Health Law 153-81.

Merryman, John Henry \& Rogelio Perez-Mordomo (2007) The Civil Law Tradition: An Introduction to the Legal Systems of Europe and Latin America. Stanford: Stanford Univ. Press.

Nutting, Charles B. (1955) "The Administrative Court," 30 New York Univ. Law Rev 1384-9.

Pintos Ager, Jesús (2000) "Scheduling Damage Awards", 1 InDret.

Ramos González, Sonia \& Luna Yerga, Álvaro (2004) "Los baremos como paradigma de valoración de daños personales - Comentario a la STS, 1aㅡ, 20.6.2003", 01 InDret.

Revesz, Richard (1990) "Specialized Courts," 138 Univ. of Pennsylvania Law Rev. 1111-74.

Ryo, Emily (2016) "Detained: A Study of Immigration Bond Hearings," 50 Law E Society Rev. 117-53.

_ (2017) "Legal Attitudes of Immigrant Detainees," 51 Law E Society Rev. $99-131$.

- (2018) "Representing Immigrants: The Role of Lawyers in Immigration Bond Hearings," 52 Law E Society Rev. 503-31.

Shavell, Steven (1987) Economic Analysis of Accident Law. Cambridge, MA: Harvard Univ. Press.

- (2010) "On the Design of the Appeals Process: The Optimal Use of Discretionary Review Versus Direct Appeal," 39 J. of Legal Studies 63-108.

Sloan, Frank A. \& Chee Ruey Hsieh (1990) "Variability in Medical Malpractice Payments: Is the Compensation Fair?" 24 Law \& Society Rev. 997-1039.

Sterett, Susan (1994) "Judicial Review in Britain," 26 Comparative Political Studies $421-42$.

(1997) Creating Constitutionalism? The Politics of Legal Expertise and Administrative Law in England and Wales. Ann Arbor: Univ. of Michigan Press.

Studdert, David M. \& Michelle M. Mello (2007) "When Tort Resolutions Are "Wrong": Predictors of Discordant Outcomes in Medical Malpractice Litigation," $36 \mathrm{~J}$. of Legal Studies S47-78.

Sugarman, Stephen D. (2005) "Comparative Law Look at Pain and Suffering Awards," 55 DePaul Law Rev. 399-434.

Visscher, Louis (2009) “Tort Damages," in Faure, Michael, ed., Encyclopedia of Law and Economics. Cheltenham, UK: Edward Elgar. 153-200.

Sofia Amaral-Garcia is a postdoc researcher at Hasselt University, Department of Economics. Previously, she was a Research Associate at DIW Berlin, Post-Doctoral Global Fellow at New York University (School of Law), and Postdoctoral Associate at ETH Zurich (Center for Law E Economics). Her research focuses on judicial behavior, empirical legal studies, comparative law E economics, and health economics. 